\title{
"PROTECTING" ASSETS THROUGH A DISCRETIONARY TRUST IN ANTICIPATION OF DIVORCE
}

\author{
Clement Marumoagae* \\ LLB LLM LLM PG Dip in Insolvency Law and \\ Practice \\ Senior Lecturer, School of Law \\ University of the Witwatersrand
}

SUMMARY

This paper addresses a dilemma faced by South African courts relating to the status of assets held in a trust of which one of the parties to a marriage is a trustee. The general rule is that trust property shall not form part of the personal estate of the trustee, except in so far as he or she, as the beneficiary, is entitled to it. This paper illustrates the possible prejudicial effect to vulnerable spouses of strictly applying trust-legal principles when deciding divorce matters. The article submits that courts should objectively assess the facts of the cases before them to determine whether the assets held in a trust would have been part of the trustee's personal estate had there been no trust created. If the answer is "yes", then such assets, depending on the marital regime, should be divided between the parties on divorce.

\section{$1 \quad$ INTRODUCTION}

South African courts are often required to determine the status of the assets held in a trust in divorce cases. ${ }^{1}$ Courts are required to decide whether trust assets, when one of the spouses is a trustee of the trust, should be regarded as part of the parties' joint-estate ${ }^{2}$ or be subject to the accrual calculation ${ }^{3}$ when the spouses are divorcing. This article assesses the manner in which the law addresses disputes relating to assets which are subject to a trust to which one of the parties to the divorce is a trustee. More particularly when there is an allegation that a trustee spouse treats trust assets as if they were

* I wish to thank Professor Elsje Bonthuys for her careful reading of the earlier draft of this manuscript and her insightful comments and suggestions. I nonetheless take full responsibility for all the views and shortcomings of this paper.

1 See generally WT $v$ KT 2015 (3) SA 574 (SCA) and Land and Agricultural Development Bank of SA v Parker [2004] 4 All SA 261 (SCA).

2 This would be when parties are married in community of property. See $D \vee D(15402 / 2010)$ [2013] (ZAGPJHC) 194 par 14, where it was held that "[t]he joint estate created by marriage in-community is held by the spouses in co-ownership, in equal, undivided shares".

3 When parties are married out-of-community of property subject to the accrual system in terms of s 3(1) of the Matrimonial Property Act 88 of 1984 (hereinafter "MPA"). 
his or her personal assets and thus should attract the application of matrimonial laws during divorce.

This article further evaluates the manner in which South African courts have dealt with the interplay between trust-law principles and matrimoniallaw principles in divorce cases. The aim is to assess whether strict reliance on trust-legal principle allows spouses to use trusts to deny their spouses at divorce the right to claim portions of assets which, had there been no trusts they would have been able to claim from. I argue that our courts, when deciding divorce cases where one of the spouses is a trustee of a discretionary trust, should develop trust-law principles in such a manner which allows the other spouse to lay a claim thereto in accordance with the parties' marital regime. More particularly, when it is evident that such a trust was established for the purposes of not only accumulating wealth for the trustee spouse, but also to protect assets from the non-trustee spouse. Furthermore, in such cases courts should read the reverse side of the trust form.

\section{DISCRETIONARY FAMILY TRUSTS}

\section{Overview}

The historical development of the concept of trust and the manner in which a trust is established have been adequately addressed in available academic literature and need not be repeated in this article. ${ }^{4}$ It suffices to mention that a trustee is appointed to hold or administer trust property separately from his or her own, for the benefit of beneficiaries. ${ }^{5}$ There are various ways in which a trust may be established, ${ }^{6}$ including by way of contract. ${ }^{7}$ The trust deed specifies the powers and functions of appointed trustees. It should also identify the assets subject to the trust, the names of the trustees and beneficiaries. A trust is not recognized in South Africa as a legal person. ${ }^{8}$

4 See Albertus "Comparing the wagf and the South African trust" in De Waal and Paleker (eds) South African Law of Succession and Trusts: The Past Meeting the Present and Thoughts for the Future (2014) 278; Du Toit "Jurisprudential Milestone in the Development of Trust Law in South Africa's Mixed Legal System" in Smith (ed) The Worlds of the Trust (2013) 258; Cameron, De Waal, Kahn, Solomon and Wunsch Honoré's South African Law of Trusts 5ed (2002) 2; De Waal "Is the DCFR trust a 'proper' trust? An evaluation from a South African perspective" 2014 Acta Juridica 219-220. See also Braun v Botha 1984 (2) SA 850 (A) par 25. S 1 of the Trust Property Control Act 57 of 1988 defines a trust as an "arrangement through which the ownership in property of one person is by virtue of a trust instrument made or bequeathed - to another person, the trustee, in whole or in part, to be administered or disposed of according to the provisions of the trust instrument for the benefit of the person or class of persons designated in the trust instrument or for the achievement of the object stated in the trust".

5 Cameron et al Honoré's South African Law of Trusts 2.

A trust can be formed in terms of a specific legislation, Court order or will.

Geach and Yeats Trusts Law and Practice (2008) 26.

- Commissioner for Inland Revenue v Friedman NNO 1993 (1) SA 353 (AD) 10. See also Land and Agricultural Development Bank of SA v Parker supra par 10. 
While there are various statutes which might affect the operation of a trust, ${ }^{9}$ nonetheless, there is no statute in South Africa which clearly outlines the requirements for the creation of a valid trust. The founder of the trust must relinquish control over the trust property in favour of the trustee. ${ }^{10}$ It is possible for the founder to be a co-trustee of the trust which he or she has created. ${ }^{11} \mathrm{~A}$ trust functions through its appointed trustees, all of whom should act together for and on behalf of the trust. ${ }^{12}$ In Theron $v$ Loubser, the Court held that the trustee is the owner of the trust property and he or she has no beneficial interest therein. ${ }^{13}$ However, this does not mean that trustees are barred from benefiting from the fruits of the trust. It is possible for the trustee to also become the beneficiary of the trust, but if he or she has not been made one of the beneficiaries, he or she should not benefit from the trust. Because the trustee administers trust property for the benefit of another, if he or she is a sole trustee, he or she may not also be the sole beneficiary of a trust. ${ }^{14}$ Even though there is no legislation mandating the appointment of independent third trustees, such trustees can prove to be important to prevent abuse of the trust, more particularly when the trustees are also beneficiaries of the trust and the beneficiaries are related to each other. ${ }^{15}$

\section{Trust created as an alter ego of the trustee}

There are two types of trusts in South Africa, an inter vivos trust which is created between living persons and a testamentary trust which is created through a valid will. ${ }^{16}$ Owing to the fact that in divorce proceedings generally, a testamentary trust which might have been created by parties to the divorce is never an issue because they are alive, the discussion of this type of trust does not warrant discussion in this article. An inter vivos trust is formed by way of a contract. Inter vivos trusts may be classified into a number of trusts, including a discretionary family trust. A discretionary family trust is normally created to protect the family wealth or assets from creditors. The beneficiaries thereto should either be named or be ascertainable from the trust deed. ${ }^{17}$ The trust deed may also grant trustees the discretion to select beneficiaries from a designated class of beneficiaries. ${ }^{18}$

9 See for instance the Administration of Estates Act 64 of 1965; Estate Duty Act 45 of 1955 (as amended); Income Tax Act 58 of 1962; Intestate Succession Act 81 of 1987; Surviving Spouse's Maintenance Act 27 of 1990 and MPA.

10 Goodricke and Son (Pty) Ltd v Registrar of Deeds, Natal 1974 (1) SA 404 (N) 408D.

11 Crookes NO v Watson 1956 (1) SA 277 (A) 282D.

12 See Steyn NNO v Block Pave (Pty) Ltd 2011 (3) SA 528.

13 Theron $v$ Loubser (161/13) [2013] ZASCA 195 par 5.

4 Land and Agricultural Development Bank of SA v Parker supra par 19.

15 Land and Agricultural Development Bank of SA v Parker supra par 34-36.

6 See Geach and Yeats Trusts Law and Practice 18.

17 Standard Bank of South Africa Limited v Swanepoel NO (20062/2014) [2015] ZASCA 71 par 8.

18 Cameron et al Honoré's South African Law of Trusts 554. 
Family discretionary trusts are vulnerable to their trustees, who may treat the assets held therein as if such assets were their personal property. ${ }^{19}$ This can occur when assets purporting to belong to the trust are in actual fact assets of the trustee, more particularly when the trustee does not appreciate the separate existence of the trust. ${ }^{20}$ These family trusts are "designed to secure the interests and protect the property of a group of family members, usually identified in the trust deed by name or by descent or by degree of kinship to the founder". ${ }^{21}$ A trust which has been created solely to protect the personal ownership interests of the trustee in the property subject to such a trust has, at times, incorrectly been referred to as a sham. A sham, as explained by English Case of Snook $v$ London and West Riding Investments $L t d,{ }^{22}$ refers to "acts done or documents executed by the parties to the 'sham' which are intended by them to give to third parties, or to the Court the appearance of creating between the parties legal rights and obligations different from the actual legal rights and obligations (if any) which the parties intend to create". According to Stafford

"[i]n the event of a sham trust, a trust inter vivos would have been created, the trust assets having been transferred to the trustee, but the trustee does not hold the assets beneficially. Thus, the trust purports to have been established on the terms of a particular trust instrument, but these terms do not reflect the parties' true intentions, the trust document being proffered with the intention of misleading third parties as to the true terms of the trust". ${ }^{23}$

A sham, from its inception, it is merely intended to deceive third parties as to the true nature of the legal "entity" which has been created, and in real terms it is not a trust at all. ${ }^{24}$ A concept of a sham is different from that of an alter ego. Unlike a sham, an alter ego trust can arise in two ways, none of which necessarily aims to deceive third parties. In the first instance, the trustees can be appointed for the purposes of merely complying with some of the formalities of creating a trust without being vested with control powers, and the trust being factually controlled by its creator. Secondly, an alter ego can result "where the trust property is treated as if it were personally owned, instead of belonging to the trust' which is more common in matrimonial proceedings". ${ }^{25}$ While a sham would invalidate a trust, ${ }^{26}$ an alter ego would not. In an alter ego trust, the trust remains valid because the requirements of creating a trust are met. However, one or more trustees usurp so much power that he, she or they control the trust property in such a manner that they directly benefit therefrom without any consequences or answering to

\footnotetext{
See Van Zyl NO v Kaye NO 2014 (4) SA 452 (WCC) par 21.

See generally Rees $v$ Harris 2012 (1) SA 583 (GSJ).

Ibid.

[1967] 2 QB 786808

23 Stafford A Legal-Comparative Study of the Interpretation and Application of the Doctrines of the Sham and the Alter-Ego in the Context of South African Trust Law: The Dangers of Translocating Company Law Principles into Trust Law (LLM Dissertation, Rhodes University 2010) 78.

24 See Stephens When to cry, "SHAM!" (LLM Dissertation, University of Cape Town 2013) 44.

25 Stafford A Legal-Comparative Study of the Interpretation and Application of the Doctrines of the Sham and the Alter-Ego in the Context of South African Trust Law 110.

26 See Van Zyl NO v Kaye supra par 19 and Khabola NO v Ralitabo NO (5512/2010) [2011] (ZAFSHC) 62 par 1-6, the latter judgment affords an example of a sham trust.
} 
either the creator or beneficiaries. ${ }^{27}$ This entails that the administration of the trust would normally be an important indicator of an alter ego trust. So much power is transferred to the trustee or trustees in such a way that the purpose for which the trust had been created is defeated. Such a trustee would be able to act unilaterally and end up among others amending the trust deed or appointing and/or dismissing other trustees without being accountable to anyone for such actions. If it is shown that the trust is wholly controlled by a trustee who derives benefit from it, then the trust may be treated as the alter ego of the trustee. ${ }^{28}$ In simple terms, in the case of a sham, there is no trust at all, while in terms of the alter ego, the trust is valid but is misused for the personal benefit of the creator or trustee, thereby justifying the piercing of the veil.

\section{Abuse of trust form necessitating the court going behind the trust}

When trusts are formed, controlled and administered, basic principles relating to trust law should always be observed. ${ }^{29} \mathrm{~A}$ trust which is an alter ego of the creator or trustee, contradicts such principles and results in the abuse of the trust form. Such abuse goes against the established principles of trust law which clearly requires trust property to be separate from a trustee's personal assets. ${ }^{30}$ The abuse is evident when the trust form is merely a cover which allows the trustee to benefit directly from the assets of the trust. ${ }^{31}$ Even though courts are cautious not to frustrate well established trust-law principles, they have nonetheless, realized that at times failure to do so might result in great injustices justifying interference with such principles. ${ }^{32}$ The Supreme Court of Appeal has recognized that occasionally it may be necessary to interfere with the trust form due to the trustee's conduct, and determine that assets allegedly vesting in trusts in fact belong to one or more of the trustees. ${ }^{33}$ The court can go behind the trust if it is clear from the facts that, while the trust is valid, nonetheless, the trustee or founder has created it as a vehicle to secure private assets, in that such assets would be part of his or her personal estate. Further, despite the trust, he or she benefits directly from such assets in the same manner he or she would have had there been no trust at all. "Going behind the trust" simply entails that the court in appropriate circumstances will turn a blind eye to the

27 See Geach and Yeats Trusts Law and Practice 1013.

28 Stafford A Legal-Comparative Study of the Interpretation and Application of the Doctrines of the Sham and the Alter-Ego in the Context of South African Trust Law 121.

29 See Van der Linde and Lombard "Identity of Interest between Trustees and Beneficiaries in so far as Object of Trust is Concerned: Effect on Validity: Nel v Metequity Ltd 2007 (3) SA 34 (SCA)" 2007 De Jure 429.

30 See Van der Merwe NO v Hydraberg Hydraulics CC 2010 (5) SA (WCC) par 14; Van der Merwe NO v Bosman 2010 (5) SA 555 (WCC) par 39.

31 Thorpe $v$ Trittenwein 2007 (2) SA 172 (SCA) par 16.

32 Van der Linde "Debasement of the Core Idea of a Trust and the Need to Protect Third Parties" 2012 THRHR 372.

33 Land and Agricultural Development Bank of SA v Parker supra par 373. 
trust and scrutinize the assets with a view of establishing who the real owner of the assets of the trust is. ${ }^{34}$

In company law terms, going behind the trust is widely referred to as "piercing or lifting the corporate veil". ${ }^{35}$ Unlike a company, a trust is not a legal person and it cannot be sued on its name. ${ }^{36}$ As such, the court in practical terms cannot disregard a trust as a separate entity in the same way it can with a company as a juristic person. It seems like what the court would be disregarding, is the alleged ownership of the trust assets by the trust as a legal institution, capable of owning assets with a view to determine who the real owner of such assets is. In $A \vee A,{ }^{37}$ it was held that "whilst section 12 of that Act provides that trust property does not form part of the personal property of a trustee; it is possible to look behind the veneer of the trust to determine who in fact owns trust property in certain circumstances". While this might be seen as an unusual and drastic measure by the courts, such action in certain instances might be necessary to prevent the abuse of a trust form. This would be most suitable in divorce matters if it is apparent that one of the parties has utilized the trust as a form of preventing the other from claiming patrimonial benefits of the marriage, which, had there been no trust, such a spouse would have been able to claim.

\section{TRUSTEES' SPOUSES' CLAIMS TO THE "TRUST ASSETS" ON DIVORCE}

\section{Marital Regimes}

The law regulating matrimonial-property regimes is well known in South Africa and ought not to be repeated in this article. ${ }^{38}$ It suffices nonetheless, to mention that if parties do not wish to get married in community of property they ought to express their intention to this effect in an antenuptual contract. Further, should they conclude an antenuptual contract, their marriage will be subject to an accrual system unless they specifically exclude this system therein. It is advisable that material consequences of a chosen marital

34 See Du Toit "South Africa - Trusts and the Patrimonial Consequences of Divorce" 2015 8(2) Journal of Civil Law Studies 658.

35 See s 20(9) of the Companies Act 71 of 2008. See also Ex Parte: Gore NO [2013] 2 All SA 437 (WCC) (in their capacities as the liquidators of 41 companies comprising King Financial Holdings Ltd (in liquidation) and its subsidiaries).

36 Lupacchini NO v Minister of Safety and Security 2010 (6) SA 457 (SCA) par 1.

37 (2013/00875) [2015] (ZAGPJHC) 259 par 59.

38 Basic family law textbooks such as Barratt, Domingo, Mahler-Coetzee, Olivier and Denson Law of Persons and the Family (2012) address the law in this regard. See also s 2 and 3 of the Matrimonial Property Act 88 of 1984 and Soupionas v Soupionas 1983 (3) SA 757 (T) 759A/B to C; Bath v Bath (952/12) [2014] ZASCA 14 par 8; B v B (700/2013) [2014] ZASCA 137 par 4 and 5, Du Plessis v Pienaar NO [2002] 4 All SA 311 (SCA) par 1, relying on Cuming v Cuming 1945 AD 201205 and Erasmus v Erasmus (1942) AD 265 273. See also Robinson "Matrimonial Property Regimes and Damages: The Far Reaches of the South African Constitution" 2007 10(3) PER 12; De Jong and Pintens "Default Matrimonial Property Regimes and the Principles of European Family Law - A European-South African Comparison (Part 1)" 20152 TSAR 363; Marumoagae "The Beginning of the End Dissolution of Marriage under Accrual System" 2015554 De Rebus 38. 
regime are well thought of by the parties; because they will be subject to its financial consequences should they divorce. ${ }^{39}$ For marriages in community of property and those where the accrual system is applicable, spouses can claim portions of the available assets during divorce proceedings. For all marriages which are out-of-community of property which are entered into before the promulgation of the Matrimonial Property Act, section 7 (3) of the Divorce $\mathrm{Act}^{40}$ allows for the redistribution of property in order to benefit the financially-weaker spouse after divorce. ${ }^{41}$

\section{Creating a trust for the protection of assets which would otherwise be subject to division upon divorce}

\section{Redistribution of Assets}

In terms of marriages in community of property and marriages where the accrual system is applicable, sharing of assets is one of the patrimonial consequences of such marriages when parties divorce. While there are a variety of reasons which might induce the founder of the trust to create a trust, ${ }^{42}$ there has been litigation where people have been accused of creating trusts in order to prevent their spouses from benefiting from assets they would have had, had such trusts not being created. Over the years, such allegations arose in the context of marriages out-of-community of property where the provisions of the MPA were not applicable, and thus the court having been called upon to make redistribution orders.

For instance, in Badenhorst $v$ Badenhorst ${ }^{43}$ the Court was required to decide whether, when making a redistribution order in terms of section 7(3) of the DA, the assets of an inter vivos discretionary trust created during the marriage must be taken into account. In this case, the parties were married to each other out of community of property and it was known that the husband was in line to inherit a farm from his father. In actual fact, a joint-will was executed by the husband's parent to the effect that such a farm would be transferred to a trust. Further it stated that the trustees would then decide when to transfer the farm to the husband against payment of R200 000, which amount was to be lent to him by the trust itself. The parties had four children and the wife played a traditional role of the mother. She also worked at the said farm by doing bookkeeping, paying wages and providing food for the workers and assisted the husband to bring improvements to the farm. The husband's father created another trust, wherein the husband and his brother were appointed as trustees, and the children of the marriage between the parties were beneficiaries thereto. The husband then started

39 See Soupionas $v$ Soupionas supra 759 A/B to C.

4070 of 1979 (hereinafter "DA").

41 See generally Bezuidenhout v Bezuidenhout [2004] 4 All SA 487 (SCA) and Beaumont v Beaumont 1987 (1) SA 967 (A).

42 For instance providing for dependants or relatives who may not be able to look after themselves or take care of their financial affairs.

432006 (2) SA 255 (SCA). 
purchasing property which he registered under the new trust and informed the wife that this was to protect them from creditors. The husband later purchased shares in a company, 50\% of which were given to the wife and the other half was registered in the name of the new trust. The Court was of the view that this was a classic example of one party "having full control of the assets of the trust and using the trust as a vehicle for his business activities. The extent of his control is evident from the provisions of the trust deed". ${ }^{44}$

Generally, in order for a court to be able to disregard the trust form and thus order that the assets held in a trust should be considered for division, the party requesting such a remedy should satisfy the court that, if the trust were not formed, such assets would have fallen into the estate of the trustee or founder of the trust. He or she must satisfy the court that the trustee or founder exercises such control over the trust which enables him or her to benefit directly from such trust. ${ }^{45}$ As far as redistribution orders are concerned, courts were willing to thoroughly assess the manner in which spouses conducted themselves with regard to all the assets which were acquired before or during the marriage. This led to the evaluation of the manner in which a spouse who is linked to the trust, treated such property in relation to such a trust. If it was found that assets were merely packed into the trust with an intention to frustrate the other spouse's claim for redistribution should the parties divorce, in such an event the courts were willing to take such assets in consideration when making redistribution orders. ${ }^{46}$ Such consideration was necessary to promote fairness and thus avoid a situation where financially-vulnerable spouses would be losing out when divorcing.

In the context of redistribution orders, courts were not necessarily concerned with the strict interpretation of trust principles to the detriment of the financially-weak spouses. While courts did not regard trusts as shams for the purposes of redistribution, they, nonetheless, were able to assess the conduct of the trustee spouse in relation to the trust. Hence, if he or she were found to have treated assets thereto as if they were his or her own personal assets, such assets would be taken into account when making a redistribution order. ${ }^{47}$

44 Badenhorst $v$ Badenhorst supra par 10. The Court further held that the husband seldom consulted or sought approval from his co-trustee brother, in that he failed to give regard to the difference between the assets of the trust and his personal assets. In making a redistribution order, the Court held that the value of the trust assets should have been added to the value of [husband]'s estate (par 11-13). See also Jordaan $v$ Jordaan 2001 (3) SA 288 (C) par 26-27, where the Court held that "sight could not be lost of the fact that the defendant had in the past used the trusts for financial gain in his personal capacity and would undoubtedly do so again in the future. It would be just and equitable if the Court, in terms of $s 7(3)$, took the assets of the trusts into account in the determination of the question as to whether it would be just and equitable to order a redistribution of assets in order to achieve a 'clean break'".

45 Badenhorst $v$ Badenhorst supra par 9.

46 Badenhorst $v$ Badenhorst supra par 10.

47 Ibid. 


\section{Accrual Sharing}

In terms of section 3 (1) of the MPA, upon divorce "[t]he spouse whose estate shows no accrual or a smaller accrual than the estate of the other spouse ..., acquires a claim against the other spouse ... for an amount equal to half of the difference between the accrual of the respective estates of the spouses". 48 If one spouse has a claim in terms of section 3(1) of the MPA, a proper calculation has to be made and the value of all assets which contributed to the growth of such a particular spouse's estate, needs to be considered. ${ }^{49}$ Prejudice would materialize if assets which would ordinarily be taken to form part of a spouse's personal estate and not excluded in accordance with either the exclusions contained in the MPA or the antenuptual contract, are held in a trust in order to protect them from an accrual claim. There has been uncertainty as to whether under such circumstances, a court can exercise its discretion in making an order that such assets should form part of the spouse's personal estate for the purposes of accrual calculation.

In $R P \vee D P, 50$ the Court was required to decide whether the assets of the discretionary trust which was created during the parties' marriage were to be taken into account in the calculation of the wife's accrual claim for the purposes of divorce. The husband was the founder of the trust and the trustees were the husband, the wife and two other people, one of whom was the husband's father. ${ }^{51}$ The wife argued that her husband who was a practising attorney and successful businessman, was literally in control of the assets of the trust, in that he did business, made financial investments and thus acquired assets virtually exclusively through the trust. ${ }^{52}$ She further argued that the trust was her husband's alter ego, in that, had there been no trust, all the assets which were held therein, would have been part of the husband's personal estate. ${ }^{53}$ The husband argued that the wife's claim that the assets of the trust be taken into account when the accrual is calculated, is not permitted by section 3 of the MPA in the same way as section 7 (3) of the DA does. ${ }^{54}$ The Court held that "[t]he only way the personal assets of a trustee can include what is notionally regarded as trust assets is by lifting the trust veil and finding that the trust is indeed the alter ego of the trustee and that, in truth and in fact, the so-called trust assets are and have always been personal assets in the estate of the trustee". ${ }^{55}$ In order to lift the trust veil it had to be shown "that the assets ostensibly owned by the trust, or some of them, are de facto the property of the [trustee], and that their value ought to be taken into account in determining the extent of accrual of the estate of the

48 See also Marumoagae 2015554 De Rebus 38.

49 The interpretation of $s 3(1)$ of the MPA and the calculation of the accrual are beyond the scope of this paper. See $B \vee B(700 / 2013)$ [2014] (ZASCA) 137.

2014 (6) SA 243 (ECP).

$51 \quad R P \vee D P$ supra par 4.

$52 \quad R P \vee D P$ supra par 7.

53 Ibid.

$4 \quad R P \vee D P$ supra par 11.

$55 \quad R P \vee D P$ supra par 35. 
[trustee]". ${ }^{56}$ South African courts are thus willing to look beyond the trust form and declare assets which would otherwise be vulnerable to an accrual claim, subject to division when the accrual is calculated.

\section{Community of Property}

Marriage in community of property "embraces all the assets of both parties (movable, immovable, corporeal or incorporeal), whether owned at the time of marriage or thereafter". ${ }^{57}$ It is important that the law does not allow for loopholes which will enable one spouse to prevent the other from benefiting from what should be marital assets when they divorce. It seems, however, that such a loophole exists with the possibility of one spouse creating a trust for the purposes of protecting assets from the other. It is through such a loophole that a question arises relating to whether assets held in a family discretionary trust, wherein one of the parties married in community of property is a trustee, can form part of the parties' joint estate. It is unfortunate that this question under South African law seems to be answered simply with reference to trust-legal principles.

It is submitted that it would be ideal to deal with this issue from the parties' marital regime's point of view. The answer to this question is found in section 12 of the Trust Property Control Act, which expressly prohibits assets held in trust from forming part of the trustee's estate, and by extension of the jointestate if he or she is married in community of property. The strict reading of this provision, where trust-legal principles become involved with divorce matters would yield prejudicial results. Such interpretation creates space for spouses to "legitimately" establish trusts and place assets which would ordinarily fall within the joint-estate, therein. ${ }^{58}$ It is submitted that strict reliance on established trust-legal principles will create problems for vulnerable spouses, in that in future more sophisticated spouses would be able to create such trusts and comply with all legal requirements of creating a trust, making it difficult for vulnerable spouses to prove that assets held in such a trust are the trustee's alter ego. It is submitted further that in such circumstances the test should neither be whether the trust is a sham nor that the assets held therein are the trustee's alter ego. The enquiry should be objective and assess whether such assets would have been part of the jointestate had there been no trust.

This problem is best illustrated in $T W v T K, 59$ where the Court was called upon to decide whether or not assets which are owned by a trust, including

56 See BC v CC 2012 (5) SA 562 (ECP) par 18, where the Court was doubtful that "value derived or enjoyed by a spouse from assets of a trust should be ignored or that the Court is precluded under s 4 of the Matrimonial Property Act from considering such value on the basis that the intention of establishing the trust is not disputed". See also Smith v Smith SECLD (Unreported) Case no 619/2006 and Pringle v Pringle (H36/2006, 18754/2007) [2009] (ZAWCHC) 207 par 12, 14 and 17.

57 Himonga "Marriage" in Du Bois (ed) Wille's Principles of South African Law (2009) 269.

58 S 15(9)(b) of the Matrimonial Property Act provides for an adjustment to be effected in favour of the other spouse upon the division of the joint-estate if there was any prejudice he or she suffered.

59 (Unreported) 2014-09-19 Case no 2010/02268. 
the former common home and the shares held by the trust in a company, form part of the joint-estate. The parties met two years before they got married and the husband convinced the wife to open a joint bank account wherein the wife deposited some of her monies. ${ }^{60}$ While they were still dating, the parties purchased a house which the husband told the wife was a good investment for both of them. ${ }^{61}$ While the parties were still dating but residing together, with the help of his father, a trust was created and held among others the husband's immovable property and shares in a company. ${ }^{62}$ The wife was under the impression that the assets which were held in the trust were for their joint-benefit. ${ }^{63}$ However, the husband merely used the trust to protect his assets from creditors which included his wife. ${ }^{64}$ The creation of a trust became a tool which would be effective in preventing the natural consequences of a marriage in community of property. Even though the parties were not married at the time, the Court accepted their income was pooled and used by the husband in their "joint account" without any objection from the wife. The Court agreed that the wife at least contributed savings from her policies as well as her retirement package to this common account. ${ }^{65}$ Clearly the wife was preparing for the parties' financial well-being while the husband was preparing a life wherein, should he marry the wife and things do not work out, the trust would assist him to preserve for himself the wealth he would have acquired at the time of divorce.

The parties got married to each other in community of property in 2001, and no children were born of their marriage. ${ }^{66}$ This effectively meant that on the strength of trust-legal principles, should the parties divorce, the wife would not share in the assets held in a trust. However, the husband would be able to share in all the assets held in the joint estate. While the trust was created by the husband's father, the trustees were the husband and his brother who played no role in the management of the trust. ${ }^{67}$ The trust was a discretionary trust and the husband could nominate beneficiaries. ${ }^{68}$ After instituting action for divorce, the husband amended the trust deed in order to include his brother's children as beneficiaries. The Court held that "trust and company were created at a time when the [husband] sought to obtain maximum wealth at minimum cost with minimum risk. He had no intention of divesting himself of any of his assets, and proposed to so structure his affairs that he could make use of all of his assets and achieve his financial objectives". ${ }^{69}$ In concluding that the assets held in the trust should form part of the joint-estate, the Court reasoned that should the "[p]olicy and legal principles dictate that the separate entity of the trust be ignored, it is a waste

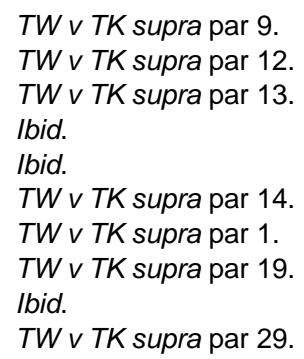


to create an entity which by a fiction is not yours but which in reality is yours with a view to excluding your wife from monies to which she would otherwise be entitled". ${ }^{70}$

This decision was appealed and overturned by the Supreme Court of Appeal. ${ }^{71}$ In this court, the first point related to whether the husband deceived and thus falsely represented to the wife that the property was to be registered in the name of the trust, with intent to protect it from his business creditors. Secondly, that the trust was the husband's alter ego, in that it was created to amass wealth for the husband and thus benefit him. ${ }^{72}$ The Court found that there was neither deceit nor misrepresentation by the husband in this matter; in that at all times the wife was aware of the existence of the trust and its ownership over the disputed assets. ${ }^{73}$ It is submitted that the Court had erred by failing to take into account the circumstances which led to the creation of the trust. The Court adopted a strict approach, in that the trust was a legitimate one created, not only on the strength of the husband's father's advice, but also created by the husband's father. Assuming that the Court's approach is correct, it is difficult to understand why the Court did not interrogate the reasons which motivated the husband's father to create a trust. In particular, due to the fact that before the amendment of the trust deed by the husband, despite the fact that the husband did not have children at the time, the beneficiaries were nonetheless the husband's children or their successors. Further, it is also not clear what assets the founder of the trust had put in the trust for the benefit of beneficiaries. What is clear are the assets (immovable property and shares) which were put into the trust by the husband, despite the fact that he was not the founder. Perhaps it might be that these issues were not argued before the Court, but given the fact that trust principles would have had an impact on the parties divorce, it is submitted that these issues should have been considered by the Court. Had the Court considered these issues, it would have realized that the trust was created solely to protect the wealth accumulated by the husband against the wife, notwithstanding the fact that the trust was created before the parties were married.

It is unfortunate that the Court justified its decision by concluding that the wife nonetheless benefited from use of the property before the parties married as well as that their joint estate subsequently benefited from the joint use of the property after the marriage, free of any consideration at both stages. ${ }^{74}$ It is submitted that the Supreme Court of Appeal failed to take into account the circumstances which led to the creation of the trust with regard to the purchase of the property and establishment of the husband's company, as demonstrated by the trial court. As such, the Court was limited in its analysis leading to lack of appreciation of the wife's claim. The wife's claim was not about the legal status or otherwise of the established trust. Neither was she contending that the trust should be regarded as non-

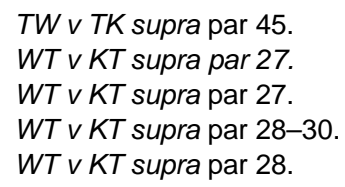


existent. It is submitted that her claim was essentially that, before the marriage, the parties planned to get married and live a comfortable life. As such, they joined their resources, with the wife contributing benefits of her policies and retirement funds, and the husband utilizing his skills to amass wealth. Further, as part of the broader planning, a trust was created, which she had been led to believe that an immovable property which was acquired in her presence would after the marriage be considered to be part of the joint-estate. Thus, it is submitted that a better approach in dealing with these issues would be to determine the status of the disputed assets and, if found that they would have fallen within the joint-estate or subject to calculation in terms of accrual system, then the trust which shields such assets should be disregarded. It is evident from the facts, as they were crafted by the trial court that both the acquisition of the immovable property and establishment of the company were at no point considered for the benefit of anyone except for the husband. Simply concluding that a trust is valid, therefore any property held thereto cannot be regarded as the personal property of the trustee, even when it is evident that the trust was just a vehicle to deny the other party what he or she would have benefitted, defeats the purpose of the parties' marital regime.

The fact that Supreme Court of Appeal accepted that the husband "drew on moneys from the trust, [and that] the joint-estate received benefits from the trust during the course of their marriage", ${ }^{75}$ should have led the Court to realize that the benefits of the trust were not awaiting any beneficiaries indicated in the trust deed, in that the husband, alone could benefit at any time without consultation with anyone from the trust. The Court blinded itself by the established trust-legal principles to a point whereby it required the wife to actually allege and prove that there was some sort of abuse of the trust form. The Court held that "unconscionable abuse of the trust form through fraud, dishonesty or an improper purpose will justify looking behind the trust form". ${ }^{76}$ It is submitted that this should not be the test in these cases. While fraud, dishonesty and an improper purpose might assist to establish that the entity created is a sham, nonetheless, the test to determine whether the trust is valid should be, but for the trust, assets held in the trust would be part of the founder or trustee's estate. If the answer is yes, then the court should go behind the trust form. This will prevent sophisticated spouses from using a trust under seemingly valid circumstances to deny their spouses from benefiting from assets as they ought to. Further, the Supreme Court of Appeal incorrectly focused on the point that the wife was not a beneficiary under the trust. ${ }^{77}$ It is submitted that this point was irrelevant under the circumstances, merely because the genesis of the wife's claim was neither to benefit from the trust nor to be declared as a beneficiary. The essence of the wife's claim was to ensure the return of assets to the parties' joint-estate which, had there been no trust, would have fallen to such joint-estate. The Court was of the view that the

\footnotetext{
WT v KT supra par 18.

WT $\vee$ KT supra par 31.

WT $\vee$ KT supra par 33.
} 
husband acquired all his possessions by his own efforts and that the wife did not have any claim relating to such assets. ${ }^{78}$

It is submitted that the Supreme Court of Appeal's approach is incorrect because it failed to accord weight to the role of the wife when the parties were not married, and how the parties pooled together their financial resources in a joint-account for their mutual benefit. While the parties might not have argued this point, nonetheless, it is submitted that the parties' relationship before the marriage indicated that universal partnership might have been formed between the parties. While the debate relating to universal partnership is beyond the scope of this paper, it suffices nonetheless, to point out that the fact that the parties resided together and also established a common account, as well as their respective financial contributions regardless of their magnitude before the marriage, might have established a universal partnership between the parties. ${ }^{79}$ On the basis of such universal partnership alone, the wife derived a claim as a partner of the union before the marriage and ought to have been allowed to claim from the assets which the husband put into the trust. Such partnership would have been made official by the contract of marriage entered into by the parties, an issue the Supreme Court of Appeal had completely disregarded in this case. The Supreme Court of Appeal upheld the appeal and held that assets held in a trust do not constitute part of the joint-estate. ${ }^{80}$

\section{CONCLUSION}

The concern relating to spouses creating trusts for the mere purposes of protecting assets from the financial consequences of the marriages they entered into, should not be taken lightly. Indeed, section 12 Trust Property Control Act provides that trust property shall not form part of the personal estate of the trustee, except in so far as he or she, as the beneficiary, is entitled to the trust property. However, this section should not be read restrictively in such a manner which would allow spouses who have chosen their marital regimes to circumvent the patrimonial consequences thereto, by creating trusts. Courts need to be vigilant and when it appears that a spouse has used a trust form as a means to avoid the circumstances of his or her marital regime through abuse of the trust entity, then such trust entity should be lifted and assets held thereto should be regarded to be those of the spouse who is abusing the trust form. Failing which, sophisticated spouses

8 WT $\vee$ KT supra par 34

79 See generally Butters v Mncora (2012) 4 SA 1 (SCA) and Ponelat $v$ Schrepfer (2012) 1 SA 206 (SCA). See Barratt "Private Contract or Automatic Court Discretion? Current Trends in Legal Regulation of Permanent Life-partnerships" 20051 Stell LR 110; Bonthuys "Developing the Common Law of Breach of Promise and Universal Partnerships: Rights to Property Sharing for all Cohabitants?" 20151 SALJ 76-99; Subramanien "A Note on 'Tacit Universal Partnerships': Clarity at Last: Ex-partner can get Slice of the Pie" 20133 Obiter 545-557.

$80 \quad$ WT $\vee$ KT supra par 40. 
would use trusts to their advantage by ensuring that the patrimonial consequences of their marital regime do not materialize when they divorce.

In this article, I argued that trust principles should be approached with caution, more particularly if they have the potential of prejudicing vulnerable parties upon divorce. In such circumstances, the court should be able to look behind the trust form and assess whether the assets held thereto, if the trust had not been established, would have been part of the trustee or founder's personal estate. Finally, the law as crafted by the Supreme Court of Appeal in $W T \vee K T$ is that generally assets of the discretionary trust do not form part of the trustee's personal estate, and thus not subject to division should such a trustee divorce his or her spouse. It is submitted that the Supreme Court of Appeal failed to take into consideration the prejudicial effect of its decision, even for future cases and thus created an environment where spouses could freely utilize trust principles to avoid consequences of the marital regimes they have chosen. ${ }^{81}$

81 See Du Toit 2015 8(2) Journal of Civil Law Studies 655, where the SCA approach seems to be supported. 